๑Ю. М. Дука

Державний заклад «Дніпропетровсъка медична академія МОЗ України»

\title{
ОЦІНКА ПРИЧИН АНОМАЛЬНОГО РОЗТАШУВАННЯ ПЛАЦЕНТИ ЗАЛЕЖНО ВІД МАСИ ТІЛА ВАГІТНОї
}

ОЦІНКА ПРИЧИН АНОМАЛЬНОГО РОЗТАШУВАННЯ ПЛАЦЕНТИ ЗАЛЕЖНО ВІД МАСИ ТІЛА ВАГІТНОЇ. У стаТТі рОЗглядаються питання залежності фрормування аномального розташування плаценти з урахуванням виявлених ендокриннометаболічних порушень, генетичного поліморфрізму в генах тромбофілії та фролатного циклу, а також із урахуванням показників гемостазу з додатковою оцінкою впливу значення індексу маси тіла вагітної на фоормування вищезгаданої патології. Доказана важливість оцінки френотипу вагітної жінки. Дано наукове та практичне обґрунтування застосування кожного напрямку в терапії в жінок із загрозою невиношування вагітності, їх важливості у профрілактиці акушерських ускладнень.

ОЦЕНКА ПРИЧИН АНОМАЛЬНОГО РАСПОЛОЖЕНИЯ ПЛАЦЕНТЫ В ЗАВИСИМОСТИ ОТ МАССЫ ТЕЛА БЕРЕМЕННОЙ. В статье рассматриваются вопросы зависимости формирования аномального расположения плаценты с учетом выявленных эндокринно-метаболических нарушений, генетического полиморфизма в генах тромбосрилии и фролатного цикла, а также с учетом данных гемостазиограммы с дополнительной оценкой влияния индекса массы телы беременной на формирование подобной патологии. Доказана важность оценки фенотипа беременной женщины. Дано научное и практическое обоснование применения каждого направления в терапии у женщин с угрозой невынашивания беременности, их важности в просилактике акушерских осложнений.

ASESSMENT OF CAUSES OF ABNORMAL PLACENTA PLACEMENT DEPENDING ON BODY WEIGHT OF PREGNANT WOMAN. The article adduces questions of dependence of formation of an abnormal arrangement of a placenta taking into account the revealed endocrine and metabolic violations, genetic polymorphism in genes of a trombofiliya and a folatny cycle, and also taking into account data of a hemostasiogram with an additional assessment of influence of body mass index of the pregnant woman on formation of similar pathology. Importance of an assessment of a phenotype of the pregnant woman is proved. Scientific and practical justification of application of each direction in therapy in women with threat of miscarriage of pregnancy, their importance in prevention of obstetric complications is given.

Ключові слова: фенотип, вагітність, невиношування, тромбофілія, аномальне розташування плаценти.

Ключевые слова: френотип, беременность, невынашивание, тромбофилия, аномальное расположение плаценты.

Key words: phenotype, pregnancy, pregnancy losses, trombophilia, abnormal arrangement of a placenta.

ВСТУП. Незважаючи на досягнення в ранній діагностиці і лікуванні порушень взаємозв'язку функціональної системи мати - плацента - плід, в практичному акушерстві залишаються проблеми, які пов'язані з розвитком плаценти і її розташуванням, актуальність яких не втрачається через велику кількість ускладнень вагітності і пологів [1, 2]. Етіологія аномального розташування плаценти (АРП) багатогранна та є проявом аномальної імплантації зародка внаслідок порушення васкуляризації децидуальної оболонки, що зумовлене атрофічними змінами або запальним процесом, які притаманні ефектам ожиріння [3-5].

Саме тому метою дослідження було виявлення кореляційних зв'язків аномальної плацентації з рядом клінічних та лабораторних показників.

МАТЕРІАЛИ ТА МЕТОДИ. ЗГідно 3 метою, дослідження було проведено на базі акушерських відділень комунального закладу «Дніпропетровський обласний перинатальний центр із стаціонаром» ДОР» м. Дніпропетровська із дотриманням основних положень протоколів наказів МО3 України № 417 та № 6243 додатковим дослідженням, 3 індивідуальної згоди жінки, поліморфрізму генів тромбофрілії та обміну фолатів за допомогою комплекту реагентів компанії «ДНК-технологія» (Росія) методом ПЛР у режимі реального часу, а також поглибленим дослідженням гемостазу та розгорнутою оцінкою ендокринно-метаболічних показників.
Статистичну обробку матеріалів дослідження проводили 3 використанням пакета програм STATISTICA v.6.1® [6]. Результати для кількісних ознак, розподіл яких відповідав нормальному закону за критерієм Колмогорова - Смірнова, представлені у вигляді кількості спостережень (n), середньої арифрметичної (M), стандартної похибки $( \pm m), 95$ \% довірчого інтервалу для середньої (95\% ДІ), в інших випадках наводяться медіана (Me) та інтерквартильний розмах [25\%; $75 \%$ ]. Порівняння статистичних характеристик у різних групах проводилось 3 використанням параметричних і непараметричних критеріїв (з урахуванням закону розподілу): перевірка рівності дисперсій - за критерієм Фішера (F); достовірність відмінностей середніх - за критеріями Стьюдента (t) і Манна - Уітні (U), відносних показників - за критерієм Хi-квадрат Пірсона $\left(\chi^{2}\right)$, у тому числі з поправкою Йетса (Yates). Для оцінки взаємозв'язку між ознаками виконувався кореляційний аналіз з розрахунком коефріцієнтів рангової кореляції Спірмена (r). Критичне значення рівня значимості (р) приймалося $\leq 0,05$.

Був проведений відбір жінок із загрозою невиношування вагітності та різною масою тіла віком від 20 до 41 року, у термін гестації до 12 тижнів, з яких сформовано дві групи спостереження - 120 (68,6 \%) жінок із загрозою невиношування вагітності на фоні надлишкової ваги - I клінічна група та 55 (31,4 \%) вагітних жінок із нормальною 
вагою (IMT 20-24,9 кг/м²) та із загрозливими для виношування вагітності симптомами - II клінічна група. Середній

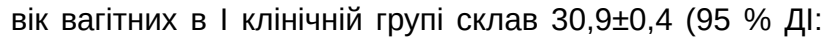

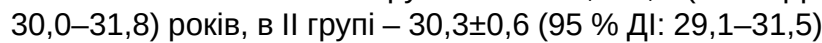
років ( $p=0,460$ за t-критерієм). Нами не було виявлено достовірних відмінностей між групами як за паритетом вагітності: $2,5[1,0 ; 4,0]$ вагітностей в I групі проти 2,0 $[1,0 ; 3,0]$ вагітностей в II групі ( $p=0,232$ за U-критерієм), так і за паритетом майбутніх пологів - 1,0 [1,0; 2,0] проти $1,0[1,0 ; 1,0]$ відповідно (p=0,086 за U). Середній гестаційний вік на момент взяття на облік у жінок тематичних

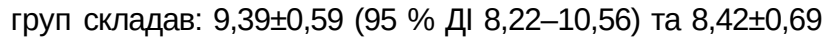
(95\% ДІ 7,03-9,81) тижня відповідно по групах ( $p=0,327)$. Середній ІМТ у жінок I клінічної групи складав 30,6士0,3

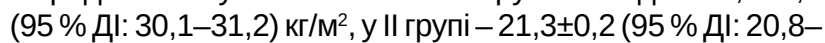
$21,8) \mathrm{k} / \mathrm{M}^{2}(\mathrm{p}<0,001)$.

РЕЗУЛЬТАТИ ДОСЛІДЖЕННЯ ТА ЇХ ОБГОВОРЕННЯ. При оцінці рівня плацентації виявлено, що у 38 (31,7 \%) та 22 (42,3 \%) пацієнток I і II груп відповідно мала місце низька плацентація ( $p=0,248$ за $\left.\chi^{2}\right)$. У 2 жінок I групи та 1 жінки II клінічної групи виявлено повне передлежання плаценти, по 2 випадки в групах жінок із надмірною вагою та у 1 жінки II клінічної групи зареєстровано неповне передлежання плаценти. Це могло пояснюватися нижчим рівнем прогестерону (P) в крові цих вагітних ( $r=0,22$, $p=0,004)$, а також рубцем на матці внаслідок кесарева розтину (КР), що мало місце в анамнезі у 2 жінок із надмірною вагою. В обох випадках підставою для виконання КР в ургентному порядку стало передчасне відшарування нормально розташованої плаценти (ПВНРП). Також рубець на матці мав місце у 3 (2,5\%) жінок I клінічної групи внаслідок консервативної міомектомії. Ризик АРП збільшувався з підвищенням кількості попередніх КР.

Додатково на необхідність пошуку кореляційних зв'язків аномальної плацентації з рядом клінічних та лабораторних показників наштовхували дані УЗД у терміні гестації 5-6 тижнів: плодове яйце у цих вагітних розташовувалося не в ділянці дна матки або правого трубного кута, які є типовими для імплантації, а в дистальних відділах, ближче до внутрішнього вічка матки, що, напевно, є наслідком більш тривалого передімплантаційного періоду. Цей фракт доводив наявність конфолікту на рівні трофробласт - слизова ендометрія. Клінічно це супроводжувалося у 39 (20 \%) вагітних виявленням супрацервікальної локалізації ретрохоріальної гематоми - 21 (17,5 \%) та 18 (32,7 \%) вагітних I та II клінічної групи відповідно $\left(p=0,042\right.$ за $\left.\chi^{2}\right)$, яка частіше супроводжувалася кров'янистими виділеннями.

Під час вивчення гормонального профрілю вагітних жінок проспективних груп були виявлені такі зміни: рівень ß-субодиниці хоріонічного гонадотропіну людини (ХГЛ) не виходив за межі нормативних значень, проте наближався до нижньої межі норми у 76 (63,3 \%) вагітних I групи та у 16 (29,1 \%) жінок II клінічної групи; гіпопрогестеронемія виявлена у $98(81,7 \%)$ і у $34(61,8 \%)$ пацієнток обох клінічних груп відповідно. Рівень Р на нижній межі норми був відзначений у 18 (15\%) жінок I клінічної групи та у 16 (29,1 \%) - другої. Рівень Р в крові відповідав параметрам норми лише у 6 (5 \%) вагітних I групи та у 5 (9,1\%) жінок II клінічної групи.

Рівні Р в жінок основних груп при взятті на облік були такими: 48,7 [36,2; 67,0] нг/мл у жінок I клінічної групи проти 71,1 [46,5; 90,8] нг/мл - у II групі (р<0,001 за U). Таким чином, в II групі його рівень майже в 1,5 раза перевищував такий рівень у жінок I групи.

Низький рівень Р асоціювався 3 наявністю і ступенем ожиріння $(r=-0,197, p=0,009)$, самостійністю настання вагітності $(r=0,274, p<0,001)$ та розвитком гестаційної артеріальної гіпертензії $(r=0,15, p=0,048)$.

Це обумовлювало необхідність застосування у цих пацієнток препаратів прогестерону. Вагітні отримували індивідуально підібрані дози мікронізованого прогестерону (від 200 до 600 мг на добу) під контролем концентрації гормону в сироватці крові. Бажаним вважали рівень Р у межах медіани референтного значення.

За показниками пренатального скринінгу (PRISCAI та PRISCA II), вираженими у відносних одиницях (MoM), у жінок I та II клінічних груп встановлені більш низькі рівні вільного естріолу ( $p=0,346$ за U-критерієм), що свідчило про сорормовану недостатність фетоплацентарного комплексу.

У жінок із надмірною вагою був встановлений прямий кореляційний зв'язок між рівнем Р та ХГЛ у терміні гестації 16-18 тижнів ( $r=0,268, p=0,004)$, в той час як у жінок 3 нормальною масою тіла вірогідних взаємозалежностей між цими показниками не виявлено $(r=0,169, p=0,216)$. Також за результатами кореляційного аналізу виявлено вірогідний зв'язок у парах: Р та показник АФП у терміні гестації 16-18 тижнів $(r=0,183, p=0,023)$.

Після дослідження на виявлення поліморфізму генів тромбофрілії, генів фролатного обміну та оцінки гемостазіологічних показників виявлений вірогідний кореляційний зв'язок у парах АРП з мутацією в гені $\mathrm{F}_{5}$-Лейден ( $\mathrm{r}=0,157$, $\mathrm{p}=0,038)$, в гені MTRR:66 $(r=0,148, p=0,050)$ та з високими рівнями Д-димеру $(r=0,167, p=0,027)$, що було відображене в клініці. Під час проведення УЗД були виявлені особливості плацентації. У 3 випадках збережених вагітностей до 20 тижнів гестації - 2 із 115 жінок I клінічної групи (1,7\%) та 1 з 52 жінок II групи (1,92 \%) - виявлено повне передлежання плаценти $\left(p=0,921\right.$ за $\left.\chi^{2}\right)$. Це асоціювалося 3 поліморфізмами в генах фрібриногену FGB 455 G>A, PAI-1: 675 5G>4G та ITGA2- $\alpha 2: 807$ C>T в усіх випадках. У кожної 3 цих жінок мали місце свої клініко-лабораторні особливості. В обох жінок мало місце звичне невиношування вагітності. В однієї жінки I клінічної групи із повним передлежанням плаценти в анамнезі була антенатальна загибель плода в терміні гестації 38 тижнів. Смерть плода настала в антенатальному періоді від асфіксії, обумовленої порушеннями кровообігу в системі мати - плацента - плід внаслідок хронічної декомпенсованої плацентарної дисфрункції. Привертав до себе увагу вкрай високий рівень загального холестерину в сироватці крові жінки - 9,38 ммоль/л. Також з АРП асоціювався високий рівень інсуліну в жінок тематичних груп ( $r=0,171 ; p=0,026)$.

Цей фракт міг пояснювати рівень плацентації, оскільки в цьому випадку мало місце порушення васкуляризації децидуальної оболонки, що було зумовлено атрофрічними змінами ендометрія. Саме тому інвазія ворсин хоріона відбувається в найбільш сприятливому місці. Додатково цьому сприяє погіршення кровообігу, зумовлене судинними змінами в ділянці прикріплення плаценти, яке $є$ наслідком змін, що відбуваються при ожирінні.

Аномальне розташування плаценти потребувало ретельного обґрунтування застосування у них антикоа- 
гулянтної терапії. Після цього встановлено, що в жодної вагітної з вищезгаданими особливостями після надходження до стаціонару та підбору індивідуальної терапії протягом усієї вагітності більше не виникали скарги на кров'янисті виділення зі статевих шляхів.

У пацієнток з неповним передлежанням плаценти міграція плаценти відбувалася повільно впродовж 10 тижнів і закінчилася в 28 тижнів гестації.

ВИСНОВКИ. 1. Жінок із надмірною масою тіла або ожирінням необхідно відокремлювати із когорти вагітних, у зв'язку із наявністю в їх організмі низки патогенетичних змін, які відображені у поєднанні найбільш поширених тромбогенних форм тромбофрілії, наявності ендотеліальних розладів, зниженні природних протитромботичних ресурсів, наявності оксидативного стресу і прозапального статусу, які додатково обумовлюють активацію системи гемостазу, посилюють ендотеліопатію й протромботичний стан, замикаючи таким чином порочне коло, що призводить до гестаційних ускладнень і перинатальних втрат.

2. Враховуючи виявлений зв'язок між виявленим аномальним розташуванням плаценти та наявністю поліморфрізму в генах тромбофрілії та фолатного циклу, необхідно проводити дослідження на материнську тромбофілію на прегравідарному етапі з метою покращення перинатальних наслідків у жінок з надмірною масою тіла та ожирінням.

3. Прегравідарна підготовка повинна включати корекцію ендокринно-метаболічних порушень 3 метою своєчасної профрілактики перинатальних ускладнень у вагітних жінок із надмірною вагою та ожирінням.

ПЕРСПЕКТИВИ ПОДАЛЬШИХ ДОСЛІДЖЕНЬ. НаДалі планується дослідити наявність залежності формування АРП із проявами ендотеліальних розладів, наявності оксидативного стресу і активації прозапального статусу у вагітних жінок із надмірною масою тіла та ожирінням.

\section{СПИСОК ЛІТЕРАТУРИ}

1. Зайнулина М. С. Пути снижения материнской и перинатальной смертности при нарушении системы гемостаза / М. С. Зайнулина // Медицинский академический журнал. 2013. - T. 13, № 1. - С. 73-82.

2. Айламазян Э. К. Наследственная тромбофилия: дифрференциальный подход к оценке риска акушерских осложнений / Э. К. Айламазян, М. С. Зайнулина // Акушерство и гинекология. - 2010. - № 3. - С. 3-9.

3. Белобородова Е. В. Клиническое значение выявления генетической и приобретенной форм гипергомоцистеинемии при ведении беременности высокого риска : авторефр. дисс. на соискание учен. степени канд. мед. наук: спец. 14.01.01 «Акушерство и гинекология» / Е. В. Белобородова. - М., 2005. - 25 c.
4. Бондарь Т. П. Генетические факторы развития тромбофилии у беременных / Т. П. Бондарь, А. Ю. Муратова // Вестник РУДН. Серия «Медицина». - 2012. - Т. 1, № 1. C. $119-120$.

5. Газиева И. А. Полиморфизмы генов фролатного обмена и показатели функционального состояния эндотелия в ранние сроки беременности: фракторы риска развития гестационных осложнений / И. А. Газиева, Г. Н. Чистякова, В. В. Ковалев // Акушерство и гинекология. - 2013. № 1. - С. 57-62.

6. Реброва О. Ю. Статистический анализ медицинских данных. Применение пакета прикладных программ STATISTICA / О. Ю. Реброва. - М. : Медиа Сфера, 2002. $-312 \mathrm{c}$. 